\title{
Erythrotropin for Treating Anemia in Multiple Myeloma: Response to Treatment and Survival
}

\author{
Yu Jiang \\ Sichuan University West China Hospital \\ Di Cao \\ Sichuan University West China Hospital \\ Juan Xu \\ Sichuan University West China Hospital \\ Ting Niu \\ Sichuan University West China Hospital \\ Yu Wu \\ Sichuan University West China Hospital \\ Huanling Zhu \\ Sichuan University West China Hospital

\section{Suping Zheng} \\ Sichuan University West China Hospital \\ Xiaomei Liao \\ Sichuan University West China Hospital \\ Caigang Xu ( $\nabla$ xucaigang@wchscu.cn) \\ Sichuan University West China Hospital
}

\section{Research article}

Keywords: Recobinant human erythropoietin, hemoglobin concentrations, curative effect, prognosis

Posted Date: July 9th, 2020

DOI: https://doi.org/10.21203/rs.3.rs-35660/v1

License: @ (1) This work is licensed under a Creative Commons Attribution 4.0 International License. Read Full License 


\section{Abstract \\ Background}

Anemia is a common complication of multiple myeloma (MM). Recombinant human erythropoietin (rhEPO) and blood transfusions are two general treatments for anemia.

\section{Methods}

In a retrospective study, we compared the efficacy and treatment response of rhEPO to those of blood transfusions on anemia and sought to determine its prognostic value in for these patients. The 94 patients who received rhEPO were divided into high-dose $(\geq 160,000 \mathrm{U} / \mathrm{month})$ and low-dose $(<160,000$ U/month) groups; 97 other patients received blood transfusions.

\section{Results}

Patients receiving rhEPO had significantly higher hemoglobin concentrations after $3(112.65 \mathrm{v} .86 .10 \mathrm{dg} / \mathrm{L})$ and $6(128.96 \mathrm{v} .91 .41 \mathrm{dg} / \mathrm{L}) \mathrm{months}$ of treatment $(P<0.001$ for both comparisons). Furthermore, the high-dose rhEPO group had higher mean hemoglobin concentrations than those of the low-dose group after $3(41 \mathrm{v} .34 \mathrm{~g} / \mathrm{L})$ and 6 (57 v. $49 \mathrm{~g} / \mathrm{L})$ months of treatment, respectively. The risks of death and relapse were significantly lower in patients receiving either dose of rhEPO that in the transfusion group. Receiving rhEPO was associated with better overall and progression-free survival (68 v. 52 months, $39 \mathrm{v}$. 27 months).

\section{Conclusions}

We believe rhEPO should be preferred to blood transfusions for treating the anemia associated with MM.

\section{Background}

Multiple myeloma (MM) is characterized by clonal proliferation of plasma cells and accounts for $10 \%$ to $15 \%$ of hematopoietic malignancies.[1] Anemia is a common complication of $\mathrm{MM}$ and is often caused when malignant cells infiltrate the bone marrow and with the reduced survival of red blood cells (RBCs), chronic renal insufficiency, cytokine production, and the myelosuppressive effects of chemotherapy. Recombinant human erythropoietin (rhEPO) and blood transfusions are two treatments for the anemia associated with MM. Compared to blood transfusions, which are characterized by transient elevations of hemoglobin concentration, rhEPO corrects anemia constantly and effectively for a long time [2].

Erythropoietin (EPO) is a hormone produced by the kidney [3] and is important in regulating the production of RBCs by binding to its receptor EPO-R, which is expressed on erythroid progenitors in the bone marrow (BM) and stimulates expansion, differentiation, and decreasing apoptosis of erythroid burst-forming unit cells.[4-6] However, although most research has verified the efficiency of EPO in prolonging survival and improving immunological functions in patients with MM,[7-20] other studies have found contradictory results in anemic patients with MM treated with rhEPO.[21,22] Therefore, we sought to determine whether rhEPO is better than blood transfusions for improving and predicting survival and in anemic patients with MM.

\section{Methods}

\section{Patients}

We abstracted data from the medical records of patients with a diagnosis of MM and anemia who were seen at West China Hospital, Sichuan University, between January 2009 and December 2014. The diagnosis of MM was based on the World Health Organization criteria,[23] and disease stage was determined by the Durie-Salmon staging system. [24] Anemia was defined as a hemoglobin concentration of less than $90 \mathrm{~g} / \mathrm{L}$.

Ethical approval was obtained from the Ethical Committee of West China Hospital before the study began.

\section{Experimental Groups and Treatment}

The patients were divided into rhEPO (94 patients) and transfusion (97 patients) groups. The rhEPO group received recombinant human erythropoietin (rhEPO, epoetin alfa) in initial doses of 40,000 to $640,000 \mathrm{U} /$ month but a general dose of 150 to $200 \mathrm{U} / \mathrm{kg}$, three times a week (about 160,000 $\mathrm{U} / \mathrm{month}$ ) in previous clinical treatment. We further divided these patients into high-dose rhEPO ( $₫ 160,000 \mathrm{U} / \mathrm{month})$ and low-dose rhEPO ( $<160,000 \mathrm{U} / \mathrm{month}) \mathrm{groups}$. The transfusion group received transfusions to maintain an essential hemoglobin concentration (above $70 \mathrm{~g} / \mathrm{L}$ ). All patients underwent chemotherapy at the beginning of treatment and received 150 to $200 \mathrm{mg} /$ day of thalidomide or $25 \mathrm{mg} /$ day of lenalidomide as maintenance treatment.

Outcomes were defined with International Myeloma Working Group criteria[25]: a stringent complete response, a complete response, a very good complete response, a very good partial response, a good partial response, stable disease, and progressive disease. A very good complete response or better was considered an effective treatment.

\section{Follow-up and Endpoints}


Patients were followed until December 2016. The duration of follow-up was determined from the date of diagnosis to either death or the end of the study. End points were relapse, death, or at the end of the study period.

\section{Statistical Methods}

All data were analyzed with the SPSS statistical software package (version 21.0; IBM Corporation, Armonk, NY). Normally distributed data are presented as means and standard deviations, and skewed data as medians and interquartile ranges. Categorical data are reported as absolute frequencies and percentages. Chi-square tests and $t$-tests were used to compare two groups for categorical data and normally distributed data, respectively. The Mann-Whitney Utest was used to compare skewed data or ordinal data. Kaplan-Meier method was used to calculate and present survival rates at 3 and 5 years after the diagnosis of the MM. Survival rates were compared between groups with the log-rank test. Univariate Cox regression analysis was used to identify independent risk factors of death. Variables significant at the 0.10 level were included in a multivariable Cox regression analysis to investigate the independent effect of MM on the outcomes. Hazard ratios (HRs) are presented with $95 \%$ confidence intervals. Alpha was set at 0.05 , and all tests were twotailed.

\section{Results}

\section{Patient Characteristics}

Median (range) follow-up of all 191 enrolled patients was 42 (4 to 92) months (Table 1). Baseline characteristics did not differ significantly between the rhEPO and transfusion groups. $48 \%$ patients were loss to follow up in our study.

\section{Hemoglobin Concentrations}

Baseline hemoglobin concentrations did not differ significantly between the rhEPO and the transfusion groups (Table 2). However, mean hemoglobin concentrations were significantly higher in of the rhEPO group than blood transfusion group after 3 months (112.65 vs. $86.10 \mathrm{~g} / \mathrm{L})$ and 6 months ( $128.96 \mathrm{vs}$ $91.41 \mathrm{~g} / \mathrm{L}$ ) treatment (Table 2).

Furthermore, subgroup analysis revealed that mean (SD) hemoglobin concentrations were significantly higher in the high-dose group than in low-dose group at 3 months ( 40.81 vs. $32.62 \mathrm{~g} / \mathrm{L}$ ) and at 6 months ( $56.98 \mathrm{vs.} 49.16 \mathrm{~g} / \mathrm{L}$, respectively; Table 3).

\section{Effective Treatment}

The percentage of effective treatment (a very good complete response or better) was significantly higher in the rhEPO group (49\%) than in the transfusion group (36\%;Table 2). Subgroup analysis in rhEPO group indicated the dose of rhEPO had no influence on response evaluation ( $P>0.05)$.

\section{Overall and Progression-Free Survival}

The Kaplan-Meier estimate of overall survival for all patients was $74 \%$ at 36 months and $52 \%$ at 60 months. Estimated progression-free survival rates for all patients were $52 \%$ at 36 months and $43 \%$ at 60 months (Figure 1 ).

Estimated overall survival rates were $82 \%$ at 36 months and $68 \%$ at 60 months in the rhEPO group and $69 \%$ at 36 months and $36 \%$ at 60 months for the transfusion group. The estimated progression free survival rates were $52 \%$ at 36 months and $31 \%$ at 60 months for the rhEPO group, and $33 \%$ at 36 months and $21 \%$ at 60 months in the transplant group. In conclusion, The rhEPO group had significantly longer progression-free and overall survival than did the transfusion group (Figure 1).

Subgroup analysis revealed that the dose of rhEPO was not associated with longer OS and PFS (Figure 2).

\section{Predictors of Progression-free and Overall Survival}

Univariate analysis identified 5 risk predictors for overall survival (cancer stage III, more than $30 \%$ of bone marrow clonal plasma cell, $\beta 2-\mathrm{MG}>3.5 \mathrm{mg} / \mathrm{L}$, a very good partial response or better, and rhEPO; Table 3). Multivariate analysis indicated that rhEPO treatment was significantly associated with improved overall survival (hazards ratio [HR], 0.44) and progression-free survival (HR, 0.61) after adjusting for cancer stage, bone marrow clonal plasma cells, serum creatinine, $\beta 2-\mathrm{MG}$, and response to treatment.

Otherwise, progression-free survival and overall survival were significantly and inversely correlated with more than $30 \% \mathrm{BM}$ clonal plasma cells (HR, 1.74 and 1.62 , respectively) and more than $3.5 \mathrm{mg} / \mathrm{L}$ of $\beta 2-\mathrm{MG}(\mathrm{HR}, 1.97$ and 1.82$)$ and was positively correlated with a very good partial response or better (HR, 0.50 and HR 0.60; Table 3).

\section{Discussion}

Anemia is a common symptom of MM, being reported in up to 70\% of patients.[26-27] Hemoglobin concentrations are important in determining the stage of MM and are closely linked to patient quality of life and tolerance to subsequent chemotherapy or stem cell transplantation.[28-29] For most patients, anemia is reduced when the disease responds to chemotherapy. When this reduction does not occur, treatment options are blood transfusions or rhEPO administration.[30] Blood transfusions are characterized by a transient elevation of hemoglobin concentrations, whereas rhEPO corrects anemia constantly and effectively for long periods.[2] 
In our study, patients treated with rhEPO had better responses to treatment and longer survival time than those treated with blood transfusions. Also, rhEPO was an independent protector of better prognosis, as reported in other studies.[15,17,18. Importantly, we studied more patients than did these related studies.( there 46 patients in Prutchi-Sagiv's study and 127 patients in Baz' study).

Recombinant human erythropoietin suppresses tumor growth and induces tumor regression through a variety of mechanisms, accelerates treatment response, and lengthens survival.[7-20,31,32] It mainly affects the immune system and even influences the proliferation of myeloma.[7-13] The erythropoietin receptor is expressed on the surface of myeloma cell lines, and activating receptor signaling reduced the viability of myeloma cell in vitro. [20] Mean serum concentrations of IgG2b and kappa light chain increased in MM mice injected with MM cells and significantly decreased in MM mice treated with EPO.[19,32] Several studies in MM mouse models have reported that EPO induced tumor regression and prolonged survival. [14,19]

In the current study, rhEPO clearly improved anemia in patients with MM, but we focused on its prognostic value and effect on clinical outcomes. On the one hand, anemia improved and allowed patients to better cope with further treatment;[33] on the other, rhEPO improved prognosis through various mechanisms. Our results confirm that rhEPO slows the progression of MM and prolongs survival.

Although rhEPO effectively treats anemia associated with MM, the optimal dose has not been determined.[34,35] We found that high-dose rhEPO was more effective than blood transfusions in treating anemia; mean hemoglobin concentrations were higher in the rhEPO group at 3 and at 6 months. Nevertheless, high-dose rhEPO did not improve treatment response or prognosis in our study and in others.[19]

We identified 4 predictors of response-to-treatment: later cancer stage, renal insufficiency, more than $30 \%$ BM clonal plasma cells, and a $\beta 2-\mathrm{MG}$ concentrations greater than $3.5 \mathrm{mg} / \mathrm{L}$ We also found that a very good partial response or better was independently protective of both progression-free and overall survival.[3640]

\section{Conclusions}

In the patients we studied, both prognosis and clinical outcomes were better with rhEPO than with blood transfusion. We believe our results support the recommendation that rhEPO should be preferred to blood transfusions for treating anemia in patients with multiple myeloma.

\section{Abbreviations}

MM: multiple myeloma

rhEPO: recombinant human erythropoietin

EPO: erythropoietin

RBCs: red blood cells

BM: bone marrow

CR: complete response

VGCR: very good partial response PR: good partial response

SD: stable disease

PD: progressive disease

HR: hazard ratio

LDH: lactate dehydrogenase $\beta 2-M G$ : beta-2 microglobulin

\section{Declarations}

Ethics approval and consent to participate: Ethical approval was obtained from the Ethical Committee of West China Hospital before the study began. Number:

2019year(218).

Consent to publish:Not applicable.

Availability of data and materials $₫$ The datasets generated and analysed during the current study are not publicly available due to privacy protection of patients but are available from the corresponding author on reasonable request.

Competing interests: There is no competing interests.

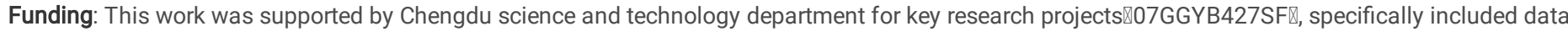
specifically includes and polishing the article. 
Authors' Contributions: All authors designed the research and drafted the manuscript. Yu Jiang and Di Cao collected and analyzed data. Yu Jiang wrote the article. The first two authors contributed equally to this paper. Di Cao is co-first author. All authors read and approved the final manuscript.

Acknowledgements: Not applicable.

\section{References}

1. Ludwig H, Pohl G, Osterborg A. Anemia in multiple myeloma. Clin Adv Hemato Oncol 2004;2(4):233-41.

2. Mimura N, Hideshima T, Anderson KC. Novel therapeutic strategies for multiple myeloma. Exp Hematol 2015 Aug;43(8):732-41. doi: 10.1016/j.exphem.2015.04.010 Epub 2015 Jun 26.

3. Bouscary D, Pene F, Claessens YE, et al. Critical role for PI 3-kinase in the control of erythropoietin-induced erythroid progenitor proliferation. Blood 2003 May 1;101(9):3436-43. Epub 2002 Dec 27. DOI:1182/blood-2002-07-2332

4. Richmond TD, Chohan M, Barber DL. Turning cells red: signal transduction mediated by erythropoietin. Trends Cell Biol 2005;15:146-55. doi:1016/j.tcb.2005.01.007

5. San Miguel JF, Bladé Creixenti J, García-Sanz R. Treatment of multiple myeloma. Haematologica 1999 Jan;84(1):36-58.

6. Krantz SB. Erythropoietin. Blood 1991;77(3):419-34.

7. Katz O, Gil L, Lifshitz L, et al. Erythropoietin enhances immune responses in mice. Eur J Immunol 2007 Jun;37(6):1584-93. doi:10.1002/eji.200637025

8. Lifshitz L, Prutchi-Sagiv S, Avneon M, Gassmann M, Mittelman M, Neumann D. Non-erythroid activities of erythropoietin: Functional effects on murine dendritic cells. Mol Immunol 2009 Feb;46(4):713-21. doi: 10.1016/j.molimm.2008.10.004. Epub 2008 Nov 22.

9. Oster HS, Prutchi-Sagiv S, Halutz O, et al. Erythropoietin treatment is associated with an augmented immune response to the influenza vaccine in hematologic patients. Exp Hematol 2013 Feb;41(2):167-71. doi: 10.1016/j.exphem.2012.10.011 Epub 2012 Oct 26.

10. Rocchetta F, Solini S, Mister M, et al. Erythropoietin enhances immunostimulatory properties of immature dendritic cells. Clin Exp Immunol 2011 Aug;165(2):202-10. doi: 10.1111/j.1365-2249.2011.04417.x Epub 2011 Jun 7.

11. Mausberg AK, Meyer Zu Hörste G, Dehmel T, et al. Erythropoietin ameliorates rat experimental autoimmune neuritis by inducing transforming growth factor-beta in macrophages. PLoS One 2011;6(10):e26280. doi: 10.1371/journal.pone.0026280 Epub 2011 Oct 17.

12. Lifshitz L, Tabak G, Gassmann M, Mittelman M, Neumann D. Macrophages as novel target cells for erythropoietin. Haematologica 2010 Nov; $95(11): 1823-$ 31. doi: 10.3324/haematol.2010.025015 Epub 2010 Jun 30.

13. Prutchi-Sagiv S, Lifshitz L, Orkin R, Mittelman M, Neumann D. Erythropoietin effects on dendritic cells: potential mediators in its function as an immunomodulator? Exp Hematol 2008 Dec;36(12):1682-90. doi: 10.1016/j.exphem.2008.07.010 Epub 2008 Oct 14.

14. Mittelman M, Neumann D, Peled A, Kanter P, Haran-Ghera N. Erythropoietin induces tumor regression and antitumor immune responses in murine myeloma models. Proc Natl Acad Sci USA 2001 Apr 24;98(9):5181-6. Epub 2001 Apr 17.

15. Prutchi-Sagiv S, Golishevsky N, Oster HS, Katz O, et al. Erythropoietin treatment in advanced multiple myeloma is associated with improved immunological functions: could it be beneficial in early disease? Br J Haematol. 2006 Dec;135(5):660-72. doi: 10.1111/j.1365-2141.2006.06366.x

16. Katz O, Barzilay E, Skaat A, Herman A, Mittelman M, Neumann D. Erythropoietin induced tumour mass reduction in murine lymphoproliferative models. Acta Haematol 2005;114(3):177-9. doi: 10.1159/000087896

17. Baz R, Walker E, Choueiri TK, Et al. Recombinant human erythropoietin is associated with increased overall survival in patients with multiple myeloma. Acta Haematol 2007;117(3):162-7. Epub 2006 Dec 5. doi: 10.1159/000097464

18. Mittelman M, Zeidman A, Kanter P, et al. Erythropoietin has an anti-myeloma effect-a hypothesis based on a clinical observation supported by animal studies. Eur J Haematol 2004 Mar;72(3):155-65. doi: 10.1046/j.0902-4441.2003.00190.x

19. Zeng Y, Zhou JL, Xu CG. [Effects of recombinant human erythropoietin on MPC-11 myeloma cells cultured in vitro]. Zhongguo Shi Yan Xue Ye Xue Za Zhi 2017 Oct;25(5):1460-5. doi:10.7534/j.issn.1009-2137.2017.05.031. Chinese

20. Våtsveen TK, Sponaas AM, Tian E, et al. Erythropoietin (EPO)-receptor signaling induces cell death of primary myeloma cells in vitro. J Hematol Oncol 2016 Aug 31;9(1):75. doi: 10.1186/s13045-016-0306-x

21. Richardson P, Schlag R, Khuageva N, et al. Characterization of haematological parameters with bortezomib-melphalan-prednisone versus melphalanprednisone in newly diagnosed myeloma, with evaluation of long-term outcomes and risk of thromboembolic events with use of erythropoiesisstimulating agents: analysis of the VISTA trial. Br J Haematol 2011 Apr;153(2):212-21. doi: 10.1111/j.1365-2141.2011.08569.x Epub 2011 Mar 6.

22. Katodritou E, Verrou E, Hadjiaggelidou C, et al. Erythropoiesis-stimulating agents are associated with reduced survival in patients with multiple myeloma. Am J Hematol. 2008 Sep;83(9):697-701. doi: 10.1002/ajh.21239

23. WHO Classification of Tumors of Haematopoietic and Lymphoid Tissues. IARC Press, Lyon 2008:200-208.

24. Greipp PR, San Miguel J, Durie BG, et al. International staging system for multiple myeloma. J Clin Oncol 2005 May 20;23(15):3412-20. Epub 2005 Apr 4.DOI: $10.1200 / J C 0.2005 .04 .242$

25. Durie BG, Harousseau JL, Miguel JS, et al.; International Myeloma Working Group. International uniform response criteria for multiple myeloma. Leukemia 2006 Sep;20(9):1467-73. Epub 2006 Jul 20.

26. Garton JP, Gertz MA, Witzig TE, et al. Epoetin alfa for the treatment of the anemia of multiple myeloma. A prospective, randomized, placebo-controlled, double-blind trial. Arch Intern Med 1995 Oct 23;155(19):2069-74. 
27. Dispenzieri A, Kyle RA. Multiple myeloma: clinical features and indications for therapy. Best Pract Res Clin Haematol 2005;18(4):553-66. 10.1016/j.beha.2005.01.008

28. Castelli R, Sciara S, Lambertenghi Deliliers G, Pantaleo G. Biosimilar epoetin alfa increases haemoglobin levels and brings cognitive and socio-relational benefits to elderly transfusion-dependent multiple myeloma patients: results from a pilot study. Ann Hematol 2016 May;96(5):779-786.DOI:1007/s00277017-2950-9.

29. Littlewood TJ, Nortier J, Rapoport B, et al.; Epoetin Alfa Study Group. Epoetin alfa corrects anemia and improves quality of life in patients with hematologic malignancies receiving non-platinum chemotherapy. Hematol Oncol 2003 Dec;21(4):169-80. doi:1002/hon.722

30. Rizzo JD, Brouwers M, Hurley P, et al.; American Society of Hematology and the American Society of Clinical Oncology Practice Guideline Update Committee. American Society of Hematology/American Society of Clinical Oncology clinical practice guideline update on the use of epoetin and darbepoetin in adult patients with cancer. Blood 2010 Nov 18;116(20):4045-59. Epub 2010 Oct 25. doi: 10.1182/blood-2010-08-300541

31. Desantis V, Frassanito MA, Tamma R, et al. rhu-Epo down-regulates pro-tumorigenic activity of cancer-associated fibroblasts in multiple myeloma. Ann Hematol 2018 Jul;97(7):1251-8. doi: 10.1007/s00277-018-3293-x

32. Deshet-Unger N, Hiram-Bab S, Haim-Ohana Y, Mittelman M, Gabet Y, Neumann D. Erythropoietin treatment in murine multiple myeloma: immune gain and bone loss. Sci Rep 2016 Aug 2;6:30998. doi: 10.1038/srep30998.

33. Rosti G, Petrini M, Bosi A, et al. Management of anaemia in oncohaematological patients treated with biosimilar epoetin alfa: results of an Italian observational, retrospective study. Ther Adv Med Oncol 2017 Jan;9(1):22-32. doi:10.1177/1758834016670554

34. Dammacco F, Castoldi G, Rödjer S. Efficacy of epoetin alfa in the treatment of anaemia of multiple myeloma. Br J Haematol 2001 April;113(1):172-9. Erratum in: Br J Haematol 2001 Sep;114(3):738.

35. Cortesi E, Mancuso A, De Pasquale Ceratti A, et al. Effectiveness and safety of an induction therapy with epoetin alfa in anemic cancer patients receiving concomitant chemotherapy. Oncologist 2004;9(4):459-68.

36. Durie BG, Salmon SE. A clinical staging system for multiple myeloma. Correlation of measured myeloma cell mass with presenting clinical features, response to treatment, and survival. Cancer 1975;36(3):842-54.

37. Pasqualetti P, Casale R, Collacciani A, Colantonio D. Prognostic factors in multiple myeloma: a new staging system based on clinical and morphological features. Eur J Cancer 1991;27(9):1123-6.

38. Biran N, Jagannath S, Chari A. Risk stratification in multiple myeloma, part 1: characterization of high-risk disease. Clin Adv Hematol Oncol 2013 Aug;11(8):489-503.

39. Abbott KC, Agodoa LY. Multiple myeloma and light chain-associated nephropathy at end-stage renal disease in the United States: patient characteristics and survival. Clin Nephrol. 2001 Sep;56(3):207-10.

40. Jacobson JL, Hussein MA, Barlogie B, Durie BG, Crowley JJ; Southwest Oncology Group. A new staging system for multiple myeloma patients based on the Southwest Oncology Group (SWOG) experience. Br J Haematol 2003 Aug;122(3):441-50.

\section{Tables}

Table 1: Characteristics or 191 Anemic Patients with Multiple Myeloma treated with rhEPO or blood Transfusions

\begin{tabular}{|llll|}
\hline & rhEPO & Transfusion group, $\mathrm{n}=97$ & \\
\hline Characteristic & group, $\mathrm{n=94}$ & & $\boldsymbol{P}$ Value \\
\hline Sex, Male/Female, $\mathrm{n} / \mathrm{n}$ & $55 / 39$ & $53 / 44$ & 0.59 \\
\hline Age at onset, mean (SD), years & $63(11)$ & $61(10)$ & 0.20 \\
\hline Disease stage(I II/III), n/n & $17 / 77$ & $11 / 86$ & 0.19 \\
\hline Hemoglobin, mean (SD), g/L & $75.50(14.76)$ & $71.96(12.52)$ & 0.08 \\
\hline Renal insufficiency, yes/no, $\mathrm{n} / \mathrm{n}$ & $19 / 75$ & $25 / 72$ & 0.36 \\
\hline Chemotherapy, $\mathrm{n}$ & & & 0.89 \\
\hline melphalan+prednisone & 32 & 29 & \\
\hline bortezomib+dexamethasone & 38 & 43 & 12 \\
\hline vincristine+doxorubicin+dexamethasone & 13 & 13 & \\
\hline cyclophosphamide+melphalan+vincristine+prednisone & 11 & & \\
\hline
\end{tabular}


Table 2: Comparison of the hemoglobin levels and response evaluation of rhEPO group and blood transfusion group

\begin{tabular}{|c|c|c|c|c|c|c|c|c|c|}
\hline \multirow[t]{2}{*}{ Group } & \multicolumn{5}{|c|}{ Response evaluation } & \multirow{2}{*}{$\begin{array}{l}\text { 3-month } \mathrm{Hg} \\
\text { Mean(SD).g/L }\end{array}$} & \multirow{2}{*}{$\begin{array}{l}\text { 6-month } \mathrm{Hg} \\
\text { Mean(SD).g/L }\end{array}$} & \multirow{2}{*}{$\begin{array}{l}\text { 3-month } \mathrm{Hg} \\
\text { increase Mean(SD).g/L }\end{array}$} & \multirow{2}{*}{$\begin{array}{l}\text { 6-month } \mathrm{Hg} \\
\text { increase } \\
\text { Mean(SD).g/ }\end{array}$} \\
\hline & $\geq \mathrm{CR}$ & VGPR & PR & SD & PD & & & & \\
\hline rHuEPO & 21 & 25 & 31 & 12 & 5 & $113.28(16.36)$ & $128.96(11.86)$ & & \\
\hline High-dose & & & & & & & & $41.04(18.80)$ & $56.83(15.82)$ \\
\hline Low-dose & & & & & & & & 33.56(13.17) & $49.10(15.72)$ \\
\hline Transfusion & 16 & 19 & 35 & 14 & 13 & $86.10(16.74)$ & $91.41(10.82)$ & & \\
\hline$P$ & 0.04 & & & & & $<0.0001$ & $<0.0001$ & 0.03 & 0.02 \\
\hline
\end{tabular}

Abbreviations: CR, complete response; VGCR, very good partial response; PR, good partial response; SD, stable disease; PD, and progressive disease

Table 3: Univariate analysis and Multivariate analysis for the risk factors in multiple myeloma

\begin{tabular}{|c|c|c|c|c|c|c|c|c|}
\hline \multirow[t]{2}{*}{ Risk factors } & \multicolumn{2}{|c|}{ Univariate analysis(OS) } & \multicolumn{2}{|c|}{ Multivariate analysis(OS) } & \multicolumn{2}{|c|}{ Univariate analysis(PFS) } & \multicolumn{2}{|c|}{ Multivariate analysis(PFS) } \\
\hline & $\mathrm{HR}(95 \% \mathrm{Cl})$ & $P$ & $\mathrm{HR}(95 \% \mathrm{Cl})$ & $P$ & $\mathrm{HR}(95 \% \mathrm{Cl})$ & $\mathrm{P}$ & $\mathrm{HR}(95 \% \mathrm{Cl})$ & $P$ \\
\hline Male, $\mathrm{n}$ & $1.084(0.722 \sim 1.627)$ & 0.6965 & & & $1.061(0.746 \sim 1.510)$ & 0.7412 & & \\
\hline Age $>60$ years & $1.188(0.789 \sim 1.789)$ & 0.4083 & & & $1.025(0.727 \sim 1.471)$ & 0.8509 & & \\
\hline Stage(stage III) & $1.845(1.045 \sim 3.403)$ & 0.0346 & $1.742(0.931 \sim 3.268)$ & 0.0824 & 1.395(0.844 2.304) & 0.1948 & & \\
\hline $\begin{array}{l}\text { Serum creatinine } \\
>176 \mathrm{umol} / \mathrm{L}\end{array}$ & $1.439(0.910 \sim 2.028)$ & 0.1197 & & & $1.631(1.099 \sim 2.421)$ & 0.0151 & $1.339(0.884 \sim 2.028)$ & 0.168 \\
\hline $\begin{array}{l}\text { Serum } \\
\text { calcium }>2.75 \mathrm{mmol} / \mathrm{L}\end{array}$ & $1.460(0.870 \sim 2.451)$ & 0.1527 & & & $1.233(0.784 \sim 1.942)$ & 0.3655 & & \\
\hline $\begin{array}{l}\text { Bone marrow clonal } \\
\text { plasma cells }>30 \%\end{array}$ & 1.938(1.264 2.967) & 0.0024 & $1.739(1.120 \sim 2.703)$ & 0.0138 & $1.835(1.274 \sim 2.646)$ & 0.0011 & 1.618(1.117 2.342) & 0.011 \\
\hline Elevated LDH & $1.412(0.929 \sim 2.151)$ & 0.1067 & & & $1.081(0.758 \sim 1.543)$ & 0.6660 & & \\
\hline$\beta 2-M G>3.5 \mathrm{mg} / \mathrm{L}$ & 2.096(1.359 3.236) & 0.0008 & $1.968(1.266 \sim 3.067)$ & 0.0026 & $2.119(1.449 \sim 3.106)$ & 0.0001 & $1.815(1.222 \sim 2.695)$ & 0.031 \\
\hline Osteolytic lesion & 1.488(0.968 2.283) & 0.3097 & & & $1.314(0.912 \sim 1.894)$ & 0.1420 & & \\
\hline $\begin{array}{l}\text { Use bortezomib in } \\
\text { Chemotherapy }\end{array}$ & $0.719(0.471 \sim 1.099)$ & 0.1275 & & & $0.759(0.530 \sim 1.088)$ & 0.1335 & & \\
\hline $\begin{array}{l}\text { Response evaluation } \\
\geq \text { VGPR }\end{array}$ & $0.465(0.303 \sim 0.713)$ & 0.0005 & $0.498(0.321 \sim 0.772)$ & 0.0018 & $0.547(0.378 \sim 0.792)$ & 0.0014 & $0.596(0.409 \sim 0.808)$ & 0.007 \\
\hline Using rhEPO & $0.539(0.357 \sim 0.815)$ & 0.0034 & $0.435(0.282 \sim 0.672)$ & 0.0002 & $0.623(0.437 \sim 0.887)$ & 0.0086 & $0.613(0.428 \sim 0.880)$ & 0.008 \\
\hline
\end{tabular}

Abbreviations: HR, hazard ratio; LDH, lactate dehydrogenase; $\beta 2-M G$, beta-2 microglobulin

\section{Figures}



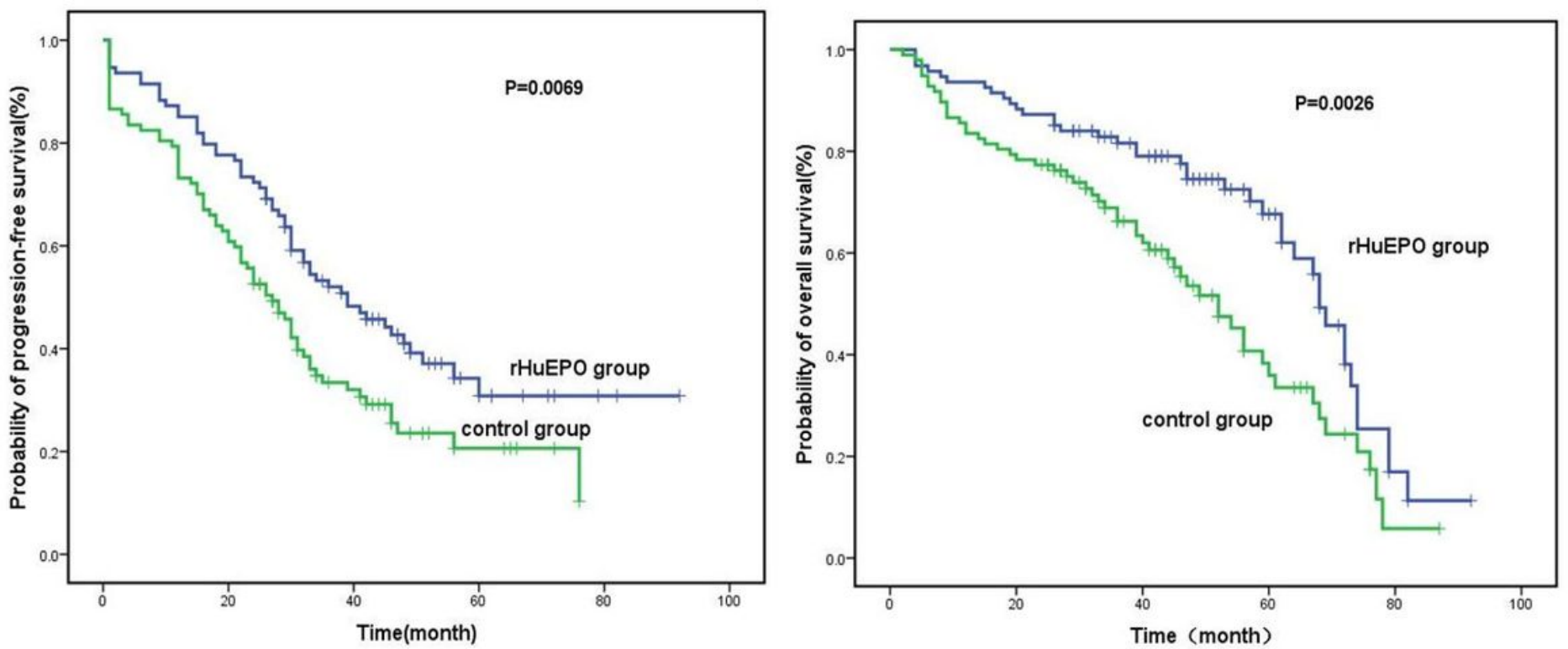

Figure 1

Comparison of the progression free survival and overall survival of rhEPO group and blood transfusion group.
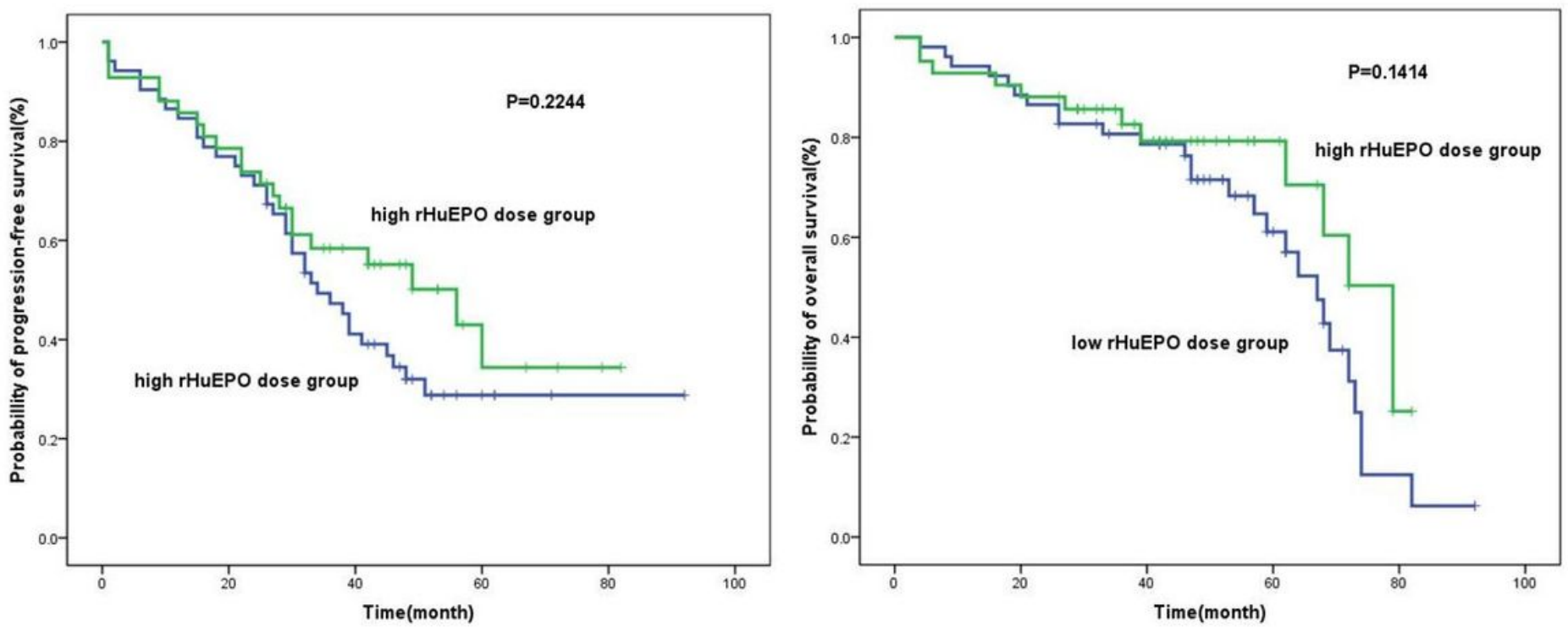

Figure 2

Subgroup analysis of patients with rhEPO treatment showed that high dose rhEPO is not associated with longer overall survival( $\mathrm{p}=0.141)$ or progression free survival $(P=0.224)$. 